\title{
Solid-state showdown: comparing the photovoltaic performance of amorphous and crystalline small-molecule diketopyrrolopyrrole acceptors
}

Tham Adhikari, ${ }^{\mathrm{a}}$, Jean-Michel Nunzi, ${ }^{\mathrm{b} *}$ and Olivier Lebel ${ }^{\mathrm{c} *}$

${ }^{a}$ Department of Chemistry, Queen's University, Kingston, K7L 3N6, Canada.

${ }^{\mathrm{b}}$ Department of Chemistry, Department of Physics, Engineering Physics and Astronomy, Queen's University, Kingston, K7L 3N6, Canada.

${ }^{\mathrm{c}}$ Department of Chemistry and Chemical Engineering, Royal Military College of Canada, Kingston, ON, K7K 7B4, Canada.

*Corresponding Author. E-mail address: nunzijm@queensu.ca (J.-M. Nunzi);

Olivier.Lebel@rmc.ca (O. Lebel).

\begin{abstract}
A novel glass-forming diketopyrrolpyrrole (DPP) derivative (DPP-glass) and a crystalline isoelectronic analogue were synthesized and their photophysical, electrochemical and photovoltaic properties were investigated. The compounds were processed into thin films that were further studied by Atomic force microscopy (AFM) and X-ray diffraction (XRD). Solution-processed inverted and regular bulk heterojunction photovoltaic cells were fabricated in different blend ratios with P3HT as donor. Both DPP derivatives show appreciable photovoltaic performance with power conversion efficiencies (PCE) ranging from 0.34-2.54\%. The regular device with amorphous DPP-glass showed the highest efficiency $(2.54 \%)$ in the blend ratio $1: 2$ whereas the device with crystalline DPP derivative shows an efficiency $1.59 \%$ under simulated 1.5 solar irradiation of 100 $\mathrm{mWcm}^{-2}$. The better performance of DPP-glass in comparison to its crystalline analogue is attributed to a more uniform film morphology and fewer defects, leading to improved electron mobility.
\end{abstract}

Keywords: molecular glasses, fullerene-free acceptor, photovoltaic cells, bulk heterojunction, morphology.

\section{Introduction}


Organic photovoltaic (PV) cells are an attractive alternative to silicon-based solar cells because of their potential for low cost, lightweight, and flexible devices for large-scale production. ${ }^{1-6}$ In two decades, significant progress has been achieved in the development of solution-processed bulk heterojunction (BHJ) organic PV cells, and the technology has reached the early stages of commercialization. ${ }^{7,8}$

Initially the most important obstacle for commercialization, the power conversion efficiency of organic photovoltaic cells has increased rapidly over the past five years using low band gap polymers as donors and fullerene derivatives as acceptors, and conversion efficiencies over $9 \%$ using several different systems have been reported since then. ${ }^{9,10}$ The bulk heterojunction is achieved by blending the n-type and p-type materials to increase the area of the interface between the donor and acceptor phases to generate more exciton dissociation/charge separation sites to yield a higher number of charges. 11,12, 13 Phase segregation of the donor and acceptor materials into distinct domains is crucial for trap-free charge transport, ${ }^{14}$ but domains that are too large (more than $\sim 10-20$ $\mathrm{nm}$ ) result in lower photocurrent due to higher recombination.

While efficiency enhancements have been primarily related to the development of improved donor polymers or small molecules that show improved properties such as high absorption, hole mobility, and adequately tuned HOMO and LUMO levels ${ }^{15,16}$, fullerene derivatives remain the most widely used acceptors due to their high electron affinity, high electron mobility, and good ability to form favorable nanoscale networks with donor materials. ${ }^{17,18}$ However, the potential of fullerenes as acceptor materials in photovoltaics suffer from some limitations: 1) they absorb weakly in the visible range, 2) the tunability of their energy levels is limited, 3) their synthesis is cost-prohibitive, and 4) their limited solubility can make their processing into thin films difficult. ${ }^{11}$

As donor materials have been developed in relation to their compatibility with fullerene acceptors, the development of acceptor materials for organic photovoltaics has been comparatively slower. ${ }^{1,12}$ However, to produce organic PV cells with optimal power conversion, it is imperative to develop better-performing acceptors. ${ }^{13}$

As an alternative to fullerenes, polymer acceptors have been used in OPV cells to reach efficiencies up to $1.8 \%$ with poly[oxa-1,4-phenylene-(1-cyano-1,2-vinylene)-(2- 
methoxy-5-(3,7-dimethyloctyloxy)-1,4-phenylene)-1,2-(2-cyanovinylene)-1,4-phenylene] (PCNEPV). ${ }^{14}$ These polymers possess certain advantages over fullerenes such as superior absorption, higher LUMO level and tunable energy levels. However, they also possess significant drawbacks such as batch-batch variation in molar mass, deep traps and defects in the acceptor polymer network. ${ }^{19}$ Small molecules such as benzothiazoles have been used as non-fullerene acceptors in bulk heterojunction PV cells with Poly(3hexylthiophene)/Polyphenylene Vinylene (P3HT/PPV) as donor. Bloking et al. reported a power conversion efficiency (PCE) of $2.54 \%$ for a solution-processed $\mathrm{P} 3 \mathrm{HT} / \mathrm{non}$ fullerene BHJ solar cell with an open-circuit voltage $\left(\mathrm{V}_{\text {oc }}\right)$ of $0.96 \mathrm{~V}$ for 4,7-bis $(4-(\mathrm{N}-$ hexyl phthalimide)vinyl)benzo[c]1,2,5-thiadiazole. ${ }^{20}$ In addition, fluoranthene-fused imide (FFI) based acceptors are another class of non-fullerene acceptors that have been used in solution processed bulk heterojunction solar cells and reported highest efficiency of $2.90 \%$ with P3HT as a donor. ${ }^{9}$ Perylenediimide-based materials are another class of promising non-fullerene acceptors, and efficiencies up to $2.3 \%$ were reported for these materials with $\mathrm{P} 3 \mathrm{HT}$ as donor. ${ }^{21}$

As most small-molecule acceptors readily crystallize, device performance can be highly sensitive to processing conditions, including deposition and annealing conditions. ${ }^{22}$ Finding optimal device fabrication conditions can therefore be time-consuming. More importantly, device performance using crystalline acceptors is also dependent on cohesion with the donor material. Proper interfacial contact between donor and acceptor domains to allow charge transport is crucial for optimal device performance, thereby making screening device fabrication conditions unnecessarily complex. ${ }^{23}$

As an alternative, small-molecule materials can also be used in the amorphous state. ${ }^{24}$ While most small molecules tend to crystallize, some compounds possess the ability to remain in the amorphous state for extended periods of time. ${ }^{14}$ Such compounds are called molecular glasses, or amorphous molecular materials, and they combine the monodisperse nature of small molecules and all the related advantages (ease of purification and characterization, batch-to-batch homogeneity) with the capacity to form high-quality amorphous thin films. ${ }^{25,26}$ Typically, compounds designed to form glasses require their molecular structures to be strategically designed for this purpose, and as a 
result possess bulky, non-planar and irregular shapes, and generally interact weakly with neighbouring molecules. To ease the design of functional molecular glasses, approaches where glass-forming derivatives of chromophores are synthesized by functionalization with peripheral groups have been reported by several groups in the literature. ${ }^{27,28}$

Mexylaminotriazines are one such family of glass-forming materials that usually show outstanding glass-forming ability, high kinetic stability towards crystallization, and glass transition temperature $\left(\mathrm{T}_{\mathrm{g}}\right)$ values that can be modulated by tuning their molecular structures. ${ }^{29-32}$ Glass-forming mexylaminotriazine derivatives can bear functional groups that can be bonded in a covalent fashion to chromophores, thereby yielding adducts that can remain indefinitely in the amorphous state at operating temperatures, while preserving the optical and electronic properties of the chromophore with minimal perturbation. ${ }^{32-34}$

Previously, our group showed that amorphous materials could be successfully used as acceptor materials in organic PV cells by reporting up to $0.66 \%$ efficiency using amorphous perylenediimide (PDI) derivatives as acceptors with benchmark donor polymer P3HT in solution-processed organic PV cells. ${ }^{32}$ While these values were in the same range as cells using analogous crystalline PDI reported by other groups as acceptors, their respective molecular structures showed enough differences to show a disparity in energy levels. As a result, an adequate comparison between amorphous and crystalline materials could not be achieved. Furthermore, simple PDI derivatives typically yield low $(<1 \%)$ conversion efficiencies with P3HT as donor, therefore more efficient alternatives were sought.

Currently, diketopyrrolopyrrole (DPP) derivatives are one of the most appealing classes of non-fullerene acceptors for many reasons: simple large-scale synthesis, high photochemical and thermal stability, strong absorption in a broad range of the visible spectrum, and strong electron-deficient character. ${ }^{35,36}$ The LUMO level of the desired materials can also easily be tuned by functionalizing the peripheral aromatic rings with a wide range of functional groups. Depending on substituents, simple small-molecule DPP 
derivatives can yield efficiencies up to $3.0 \%$ with $\mathrm{P} 3 \mathrm{HT}$ as donor. ${ }^{37}$

In this work, a glass-forming rhodanine-subsituted DPP derivative containing a mexylaminotriazine group (DPP-glass), along with a crystalline analogue with an ethyl chain (DPP-Et), were synthesized, characterized and incorporated into organic photovoltaic cells with P3HT as donor. In the devices using DPP-glass, the acceptor domains remained amorphous, while in devices with DPP-Et crystallization occurred upon annealing. Interestingly, efficiencies up to $2.54 \%$ could be attained with devices using DPP-glass, compared to $1.59 \%$ in devices using its crystalline analogue DPP-Et. The use of an amorphous acceptor material thus resulted in a higher performance than with a closely similar crystalline material, despite the glass-forming material containing larger non-electroactive groups.

\section{Experimental}

\subsection{General}

The patterned Indium tin oxide (ITO) coated glasses used as substrates were purchased from Luminescence Technology Corporation, with ITO film thickness approximately $135 \pm 15 \mathrm{~nm}$ and sheet resistance $15 \Omega \mathrm{sq}^{-2}$. Regioregular poly (3hexylthiophene-2,5-diyl (P3HT) used as electron donor was purchased from Rieke Metals. Molybdenum oxide used as hole transport layer was purchased from Alfa Aesar. Zinc oxide $(\mathrm{ZnO})$ used as electron transporting material was synthesized by the sol-gel method as reported in the literature. $^{2}$ 2-Mexylamino-4-methylamino-6-(2aminoethyl)amino-1,3,5-triazine (1) and 2,5-dihexyl-3-(5-bromothiophene-2-yl)-6(thiophene-2-yl)pyrrolo[3,4-c]pyrrole-1,4-dione (3) were synthesized according to literature procedures. ${ }^{33,38}$ All other reagents were purchased from commercial sources and used without further purification. Glass transition temperatures were determined with a TA Instruments 2010 Differential Scanning Calorimeter calibrated with indium at a heating rate of $5{ }^{\circ} \mathrm{C} / \mathrm{min}$ from 30 to $250{ }^{\circ} \mathrm{C}$. Values were reported as the half-height of the heat capacity change averaged over two heating runs. FTIR spectra were acquired with thin films cast from $\mathrm{CH}_{2} \mathrm{Cl}_{2}$ on $\mathrm{KBr}$ windows using a Perkin-Elmer Spectrum 65 
spectrometer. NMR spectra were acquired on either a $400 \mathrm{MHz}$ Bruker AV400 or on a $300 \mathrm{MHz}$ Varian Oxford spectrometer. UV-Visible absorption spectra were acquired using a Hewlett-Packard 8453 spectrometer or an Olid ${ }^{\circledR}$ HP8452 Diode Array Spectrometer. Luminescence was measured with a USB2000-Ocean Optics spectrometer. XRD data were obtained using an Xpert Pro Philips powder X-ray diffractometer. The morphology of DPP-glass derivatives films and P3HT/DPP-rhodanine films were characterized using an Ambios Multimode Atomic Force Microscope (AFM) in tapping mode with $300 \mathrm{KHz}$ resonant frequency cantilever. Current density-voltage (J-V) measurements were carried out using a Keithley 4200-SCS in the dark and under illumination. All the photovoltaic parameters of the inverted cells were measured at ambient conditions using a Xenon light with an intensity of $100 \mathrm{mWcm}^{-2}$ calibrated with an AM 1.5 solar simulator.

\subsection{Synthesis}

\section{Synthesis of Rhodanine Glass 2:}

To a mixture of $\mathrm{NH}_{2}$-glass $1(5.0 \mathrm{~g}, 17.4 \mathrm{mmol})$ and triethylamine $(6.48 \mathrm{~mL}, 4.71 \mathrm{~g}, 46.5$ $\mathrm{mmol})$ in methanol $(50 \mathrm{~mL})$ in a round-bottomed flask equipped with a magnetic stirrer was added $\mathrm{CS}_{2}(1.05 \mathrm{~mL}, 1.32 \mathrm{~g}, 17.4 \mathrm{mmol})$ dropwise at ambient temperature. The mixture was stirred $1 \mathrm{~h}$, at which point KI (0.289 g, $1.74 \mathrm{mmol})$ and ethyl chloroacetate (1.92 mL, $2.19 \mathrm{~g}, 17.9 \mathrm{mmol})$ were added, and the mixture was allowed to stir for $18 \mathrm{~h}$ at ambient temperature. $\mathrm{CH}_{2} \mathrm{Cl}_{2}$ and aq. $\mathrm{AcOH}(1 \mathrm{M})$ were then added, and both layers were separated. The organic layer was recovered, washed with aq. $\mathrm{NaHCO}_{3}$ and $\mathrm{H}_{2} \mathrm{O}$, dried over $\mathrm{Na}_{2} \mathrm{SO}_{4}$, filtered, and the volatiles were evaporated under reduced pressure. The crude product was triturated in $\mathrm{MeOH}$ then filtered on a short silica pad with AcOEt to yield, after thorough drying, $4.76 \mathrm{~g}$ pure compound 2 (11.8 mmol, $68 \%$ ): $\mathrm{T}_{\mathrm{g}} 76^{\circ} \mathrm{C}$; FTIR $\left(\mathrm{KBr} / \mathrm{CH}_{2} \mathrm{Cl}_{2}\right)$ 3404, 3274, 3945, 2921, 2859, 1625, 1604, 1581, 1561, 1524, 1434 , 1396, 1362, 1326, 1216, 1201, 1144, 1104, 1086, 1066, 1026, 998, 882, 840, 808, 735, $687 \mathrm{~cm}^{-1} ;{ }^{1} \mathrm{H}$ NMR (400 MHz, DMSO- $\left.d_{6}, 363 \mathrm{~K}\right) \delta 8.27(\mathrm{~s}, 1 \mathrm{H}), 7.37(\mathrm{~s}, 2 \mathrm{H}), 6.57$ (s, 1H), 6.48 (br s, 1H), 6.31 (br s, 1H), 4.15 (t, $\left.{ }^{3} J=5.9 \mathrm{~Hz}, 2 \mathrm{H}\right), 4.13$ (s, 2H), 3.58 (q, ${ }^{3} J=$ $5.9 \mathrm{~Hz}, 2 \mathrm{H}), 2.83\left(\mathrm{~d},{ }^{3} \mathrm{~J}=4.1 \mathrm{~Hz}, 3 \mathrm{H}\right), 2.23(\mathrm{~s}, 6 \mathrm{H}) \mathrm{ppm} ;{ }^{13} \mathrm{C}$ NMR (100 MHz, DMSO- 
$\left.d_{6}\right) \delta 203.2,174.4,165.6,163.5,140.3,136.9,122.7,117.2,43.8,37.2,35.5,27.1,21.2$ ppm; HRMS (ESI, $\mathrm{MNa}^{+}$) calcd. for $\mathrm{C}_{17} \mathrm{H}_{21} \mathrm{NaN}_{7} \mathrm{OS}_{2} \mathrm{~m} / \mathrm{e}$ : 426.1141, found: 426.1134 .

\section{Synthesis of 4-formylphenyl-DPP 4:}

Monobromo DPP precursor 3 (0.548 g, $1.00 \mathrm{mmol})$, 4-formylphenylboronic acid (0.187 $\mathrm{g}, 1.25 \mathrm{mmol})$ and $\mathrm{K}_{2} \mathrm{CO}_{3}(0.173 \mathrm{~g}, 1.25 \mathrm{mmol})$ were added to $\mathrm{PhCH}_{3} / \mathrm{EtOH} / \mathrm{H}_{2} \mathrm{O}(3: 1: 1)$ $(35 \mathrm{~mL})$ in a round-bottomed flask equipped with a magnetic stirrer and a water-jacketed condenser. The mixture was degassed by purging $\mathrm{N}_{2}$ for $15 \mathrm{~min}$, then $\mathrm{Pd}\left(\mathrm{PPh}_{3}\right)_{4}(0.035 \mathrm{~g}$, $0.03 \mathrm{mmol}$ ) was added, and the mixture was refluxed $18 \mathrm{~h}$ under $\mathrm{N}_{2}$ atmosphere. After cooling down to ambient temperature, $\mathrm{CH}_{2} \mathrm{Cl}_{2}$ and $\mathrm{H}_{2} \mathrm{O}$ were added, then both layers were separated and the remaining precipitate was discarded. The aqueous layer was extracted twice with $\mathrm{CH}_{2} \mathrm{Cl}_{2}$, then the combined organic extracts were dried over $\mathrm{Na}_{2} \mathrm{SO}_{4}$, filtered, and the volatiles were removed under vacuum. The crude product was purified on silica using $\mathrm{CH}_{2} \mathrm{Cl}_{2}$ as eluent to afford, after drying, $0.370 \mathrm{~g}$ of the title compound (0.646 mmol, $65 \%$ ): $\mathrm{T}_{\mathrm{m}} 205{ }^{\circ} \mathrm{C}$; FT-IR $\left(\mathrm{KBr} / \mathrm{CH}_{2} \mathrm{Cl}_{2}\right)$ 2953, 2925, 2856, 1727, 1705, 1658, 1600, 1558, 1462, 1417, 1404, 1369, 1338, 1306, 1281, 1240, 1230, 1212, 1171, $1120,1102,1080,1069,1024,858,834,808,730,704,691 \mathrm{~cm}^{-1}$; ${ }^{1} \mathrm{H}$ NMR $(400 \mathrm{MHz}$, $\left.\mathrm{CDCl}_{3}\right) \delta 10.02(\mathrm{~s}, 1 \mathrm{H}), 8.95\left(\mathrm{~d},{ }^{3} J=4.2 \mathrm{~Hz}, 1 \mathrm{H}\right), 8.93\left(\mathrm{~d},{ }^{3} J=4.2 \mathrm{~Hz}, 1 \mathrm{H}\right), 7.92\left(\mathrm{~d},{ }^{3} J=\right.$ $8.2 \mathrm{~Hz}, 2 \mathrm{H}), 7.82\left(\mathrm{~d},{ }^{3} J=8.2 \mathrm{~Hz}, 2 \mathrm{H}\right), 7.65(\mathrm{~d}, 4.2 \mathrm{~Hz}, 1 \mathrm{H}), 7.59\left(\mathrm{~d},{ }^{3} J=4.2 \mathrm{~Hz}, 1 \mathrm{H}\right)$, $7.29\left(\mathrm{t},{ }^{3} \mathrm{~J}=4.2 \mathrm{~Hz}, 1 \mathrm{H}\right), 4.09(\mathrm{~m}, 4 \mathrm{H}), 1.76(\mathrm{~m}, 4 \mathrm{H}), 1.44(\mathrm{~m}, 4 \mathrm{H}), 1.33(\mathrm{~m}, 8 \mathrm{H}), 0.90$ (m, 6H) ppm; ${ }^{13} \mathrm{C}$ NMR $\left(100 \mathrm{MHz}, \mathrm{CDCl}_{3}\right) \delta$ 191.2, 161.2, 161.2, 147.3, 140.3, 138.9, 138.6, 136.3, 135.9, 135.6, 132.1, 132.0, 131.9, 131.0, 130.5, 129.6, 128.7, 128.5, 128.4, $126.3,108.5,107.7,42.2,31.4,29.9,26.5,22.5,14.0$ ppm; UV-Vis $\left(\mathrm{CH}_{2} \mathrm{Cl}_{2}\right): \lambda_{\max }(\varepsilon)$ $369 \mathrm{~nm}$ (32000), $547 \mathrm{~nm}$ (36500), $576 \mathrm{~nm}$ (38500); HRMS (ESI, $\mathrm{MNa}^{+}$) calcd. for $\mathrm{C}_{33} \mathrm{H}_{36} \mathrm{NaN}_{2} \mathrm{O}_{3} \mathrm{~S}_{2}$ m/e: 595.2060 , found: 595.2048.

\section{Synthesis of DPP-glass 5:}

4-Formylphenyl-DPP 4 (1.00 g, $1.75 \mathrm{mmol})$, rhodanine-glass 2 (0.885 g, $2.19 \mathrm{mmol})$ and piperidine $(0.216 \mathrm{~mL}, 0.186 \mathrm{~g}, 2.19 \mathrm{mmol})$ were successively added in $\mathrm{PhCH}_{3} / \mathrm{EtOH}$ 1:1 $(50 \mathrm{~mL})$ in a round-bottomed flask equipped with a magnetic stirrer and a water-jacketed condenser. The mixture was refluxed for $18 \mathrm{~h}$, after which the volatiles were removed 
under vacuum. The residue was purified on silica with $\mathrm{CH}_{2} \mathrm{Cl}_{2}$ to remove unreacted starting material, then $\mathrm{AcOEt} / \mathrm{CH}_{2} \mathrm{Cl}_{2}$ 1:1 to recover the desired product. $1.47 \mathrm{~g}$ pure compound 5 were thusly obtained after drying (1.54 mmol, $88 \%$ ): $\mathrm{Tg}_{\mathrm{g}} 89^{\circ} \mathrm{C}$; FT-IR $\left(\mathrm{KBr} / \mathrm{CH}_{2} \mathrm{Cl}_{2}\right) 3410,3294,3084,2953,2928,2870,2856,1714,1661,1586,1558,1524$, 1438, 1405, 1377, 1361, 1323, 1285, 1247, 1231, 1205, 1186, 1142, 1099, 1069, 1031, $955,898,858,835,808,732,707,688 \mathrm{~cm}^{-1} ;{ }^{1} \mathrm{H}$ NMR (400 MHz, DMSO- $\left.d_{6}, 363 \mathrm{~K}\right) \delta$ $8.77\left(\mathrm{~d},{ }^{3} J=4.1 \mathrm{~Hz}, 1 \mathrm{H}\right), 8.73\left(\mathrm{~d},{ }^{3} J=4.1 \mathrm{~Hz}, 1 \mathrm{H}\right), 8.15(\mathrm{br} \mathrm{s}, 1 \mathrm{H}), 8.04\left(\mathrm{~d},{ }^{3} J=4.1 \mathrm{~Hz}\right.$, 1H), $7.90\left(\mathrm{~d},{ }^{3} J=8.3 \mathrm{~Hz}, 2 \mathrm{H}\right), 7.87\left(\mathrm{~d},{ }^{3} J=4.1 \mathrm{~Hz}, 1 \mathrm{H}\right), 7.70(\mathrm{~s}, 1 \mathrm{H}), 7.65\left(\mathrm{~d},{ }^{3} J=8.3\right.$ Hz, 2H), 7.38 (t, $\left.{ }^{3} J=4.1 \mathrm{~Hz}, 1 \mathrm{H}\right), 7.31(\mathrm{~s}, 2 \mathrm{H}), 6.53$ (s, 1H), 6.52 (br s, 1H), 6.24 (br s, $1 \mathrm{H}), 4.32\left(\mathrm{t},{ }^{3} J=5.6 \mathrm{~Hz}, 2 \mathrm{H}\right), 4.04(\mathrm{~m}, 4 \mathrm{H}), 3.69(\mathrm{~m}, 2 \mathrm{H}), 2.79\left(\mathrm{~d},{ }^{3} J=4.8 \mathrm{~Hz}, 3 \mathrm{H}\right), 2.20$ (s, 6H), $1.69(\mathrm{~m}, 4 \mathrm{H}), 1.39(\mathrm{~m}, 4 \mathrm{H}), 1.32(\mathrm{~m}, 8 \mathrm{H}), 0.87\left(\mathrm{t},{ }^{3} \mathrm{~J}=5.9 \mathrm{~Hz}, 6 \mathrm{H}\right) \mathrm{ppm} ;{ }^{13} \mathrm{C}$ NMR (100 MHz, DMSO-d $\left.d_{6}\right) \delta 192.6,170.2,166.7,165.9,163.7,159.6,146.9,140.4$, 138.4, 137.6, 136.8, 136.1, 134.8, 133.4, 132.3, 131.4, 130.8, 128.8, 128.7, 128.5, 128.0, $125.8,125.3,122.5,121.8,117.1,106.8,106.4,44.0,41.4,37.3,30.7,29.1,27.1,25.9$, 25.1, 22.0, 21.1, $13.8 \mathrm{ppm}$; UV-Vis $\left(\mathrm{CH}_{2} \mathrm{Cl}_{2}\right): \lambda_{\max }(\varepsilon) 432 \mathrm{~nm}$ (32000), $576 \mathrm{~nm}$ (40800); HRMS (ESI, $\mathrm{MH}^{+}$) calcd. for $\mathrm{C}_{50} \mathrm{H}_{56} \mathrm{~N}_{9} \mathrm{O}_{3} \mathrm{~S}_{4}$ m/e: 958.3383 , found: 958.3409 .

\section{Synthesis of DPP-Et-rhodanine 6:}

4-Formylphenyl-DPP 4 (0.445 g, $0.777 \mathrm{mmol})$, ethylrhodanine $(0.251 \mathrm{~g}, 1.55 \mathrm{mmol})$ and piperidine $(0.153 \mathrm{~mL}, 0.132 \mathrm{~g}, 1.55 \mathrm{mmol})$ were successively added in $\mathrm{PhCH}_{3} / \mathrm{EtOH}$ 1:1 $(20 \mathrm{~mL})$ in a round-bottomed flask equipped with a magnetic stirrer and a water-jacketed condenser. The mixture was refluxed for $18 \mathrm{~h}$, after which the volatiles were removed under vacuum. The residue was re-dissolved in minimal $\mathrm{CH}_{2} \mathrm{Cl}_{2}$, poured in hexanes, and the resulting precipitate was collected by filtration and washed abundantly with hot hexanes to yield, after drying under air, $0.263 \mathrm{~g}$ compound 6 (0.367 mmol, $47 \%$ ): $\mathrm{T}_{\mathrm{m}}$ $176{ }^{\circ} \mathrm{C}$; FT-IR $\left(\mathrm{KBr} / \mathrm{CH}_{2} \mathrm{Cl}_{2}\right)$ 2954, 2926, 2871, 2855, 1710, 1658, 1584, 1556, 1528, 1496, 1455, 1435, 1416, 1404, 1375, 1343, 1324, 1287, 1248, 1228, 1192, 1138, 1102, 1085, 1066, 1027, 1011, 898, 859, 842, 811, 764, 730, $703 \mathrm{~cm}^{-1}$; ${ }^{1} \mathrm{H}$ NMR (400 MHz, $\left.\mathrm{CDCl}_{3}\right) \delta 8.95\left(\mathrm{~d},{ }^{3} J=4.2 \mathrm{~Hz}, 2 \mathrm{H}\right), 7.77\left(\mathrm{~d},{ }^{3} J=8.2 \mathrm{~Hz}, 2 \mathrm{H}\right), 7.70(\mathrm{~s}, 1 \mathrm{H}), 7.65\left(\mathrm{~d},{ }^{3} J=\right.$ $4.2 \mathrm{~Hz}, 1 \mathrm{H}), 7.56\left(\mathrm{~d},{ }^{3} J=4.2 \mathrm{~Hz}, 1 \mathrm{H}\right), 7.53\left(\mathrm{~d},{ }^{3} J=8.2 \mathrm{~Hz}, 2 \mathrm{H}\right), 7.29\left(\mathrm{t},{ }^{3} J=4.2 \mathrm{~Hz}, 1 \mathrm{H}\right)$, $4.21\left(\mathrm{q},{ }^{3} J=7.1 \mathrm{~Hz}, 2 \mathrm{H}\right), 4.09\left(\mathrm{q},{ }^{3} J=6.7 \mathrm{~Hz}, 4 \mathrm{H}\right), 1.77(\mathrm{~m}, 4 \mathrm{H}), 1.44(\mathrm{~m}, 4 \mathrm{H}), 1.34(\mathrm{~m}$, 
$8 \mathrm{H}), 1.30\left(\mathrm{t},{ }^{3} J=7.1 \mathrm{~Hz}, 3 \mathrm{H}\right), 0.90(\mathrm{~m}, 6 \mathrm{H}) \mathrm{ppm} ;{ }^{13} \mathrm{C} \mathrm{NMR}\left(100 \mathrm{MHz}, \mathrm{CDCl}_{3}\right) \delta 192.5$, $167.5,161.3,147.7,140.2,139.1,136.6,135.5,135.0,133.4,131.6,131.4,131.0,130.1$, 129.7, 128.7, 126.6, 125.8, 123.5, 108.4, 107.8, 42.2, 39.9, 31.4, 29.9, 29.7, 26.5, 22.5, 14.0, 12.3 ppm; UV-Vis $\left(\mathrm{CH}_{2} \mathrm{Cl}_{2}\right): \lambda_{\max }(\varepsilon) 429 \mathrm{~nm}$ (33000), $576 \mathrm{~nm}$ (38500); HRMS (ESI, $\mathrm{MNa}^{+}$) calcd. for $\mathrm{C}_{38} \mathrm{H}_{41} \mathrm{NaN}_{3} \mathrm{O}_{3} \mathrm{~S}_{4}$ m/e: xxx.xxxx, found: xxx.xxxx.

\subsection{Cyclic Voltammetry}

Cyclic voltammograms were recorded using an EG\&G Model 263 potentiostat connected with three electrodes: working electrode (glassy carbon-carbon), reference electrode ( $\mathrm{Ag} / \mathrm{AgCl}$ (in $3 \mathrm{M} \mathrm{NaCl}$ ) and counter or auxiliary electrode $(\mathrm{Pt}) .0 .01 \mathrm{M}$ solutions of DPP derivatives 5-6 and 0.1M n-Bu4 $\mathrm{NPF}_{6}$ were prepared in acetonitrile. The electrolytic cell was previously cleaned with acetonitrile, half filled with $0.1 \mathrm{M} \mathrm{n}-\mathrm{Bu}_{4} \mathrm{NPF}_{6}$ and outgassed with bubbling $\mathrm{N}_{2}$. A small amount of ferrocene was added to it as internal standard and stirred, then the cyclovoltammograms were recorded at a scan rate of $50 \mathrm{mvs}^{-1}$.

\subsection{Device Fabrication}

Devices were fabricated according to a previously published procedure. ${ }^{3}$ Pre-patterned ITO substrates obtained from commercial sources were cleaned consecutively in an ultrasonic bath with detergent powder, distilled water, propanone-2 and 2-propanol for 20 minutes each and finally dried with air. The substrates were heated on hot plate at $100{ }^{\circ} \mathrm{C}$ for 30 minutes to modify the surface of ITO-glass. The dried substrates were further cleaned with a plasma cleaner for 20 minutes. $\mathrm{ZnO}$ precursor gel was spin-coated on cleaned ITO substrate at a rate of $3000 \mathrm{rpm}$ in air. The substrates coated with $\mathrm{ZnO}$ were baked at $200{ }^{\circ} \mathrm{C}$ for $1 \mathrm{~h}$. The thickness of $\mathrm{ZnO}$ was approximately $30 \mathrm{~nm}$. Blend solutions of P3HT and DPP derivatives were prepared in chlorobenzene in different ratios by weight $(2: 1,1: 1$ and $1: 2)$ and stirred for $24 \mathrm{~h}$ at $40{ }^{\circ} \mathrm{C}$. The solutions were filtered through a $0.45 \mu \mathrm{m}$ poly(tetrafluoroethylene) (PTFE) filter before active layer deposition. The active layer was spin-coated at $2000 \mathrm{rpm}$ and annealed at $110{ }^{\circ} \mathrm{C}$ for 15 minutes. The thickness of the active layer was measured with a Sloan Dektak II profilometer to range from 100-120 nm. The top and bottom electrodes of the devices were cleaned with a 
cotton stick soaked with chloroform to make contacts. Finally, $6 \mathrm{~nm}$ of $\mathrm{MoO}_{3}$ and $80 \mathrm{~nm}$ of Ag were deposited with deposition rates of $0.2 \mathrm{~A} / \mathrm{s}$ and $1.0 \mathrm{~A} / \mathrm{s}$, respectively, on all the devices using a physical vapour deposition system (PVD) under high vacuum at a pressure of $6 \times 10^{-6} \mathrm{mBar}$. The active area of the device was $6 \mathrm{~mm}^{2}$. The inverted device structure and energy alignment is shown in Figure 1a-b.

For conventional device fabrication, poly(3,4-ethylenedioxythiophene) polystyrene sulfonate (PEDOT: PSS) was deposited by spin-coating onto cleaned patterned ITO-glass at $4000 \mathrm{rpm}$ and annealed at $140{ }^{\circ} \mathrm{C}$ for 20 minutes. The active layer was spin-coated at $2000 \mathrm{rpm}$ range. Finally, $10 \mathrm{~nm}$ Bathocuproine (BCP) and $100 \mathrm{~nm}$ of $\mathrm{Al}$ were deposited with deposition rates of $0.2 \AA / \mathrm{s}$ and $1.0 \AA / \mathrm{s}$, respectively, on all the devices using a physical vapor deposition system (PVD). The regular device structure and energy alignment is shown in Figure 1c-d.

(a)

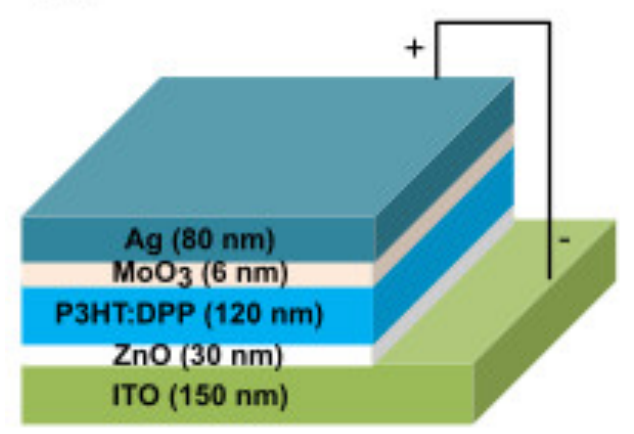

(c)

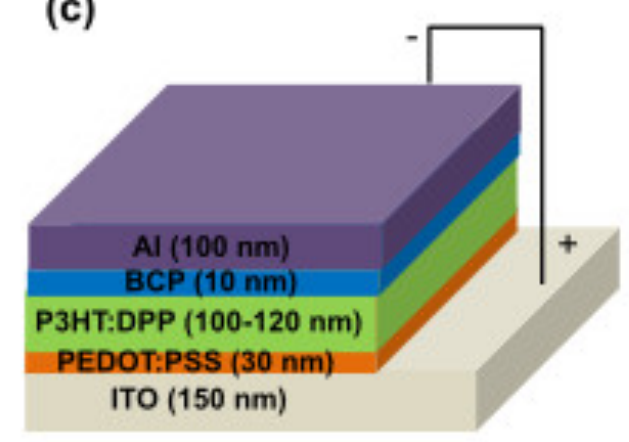

(b)

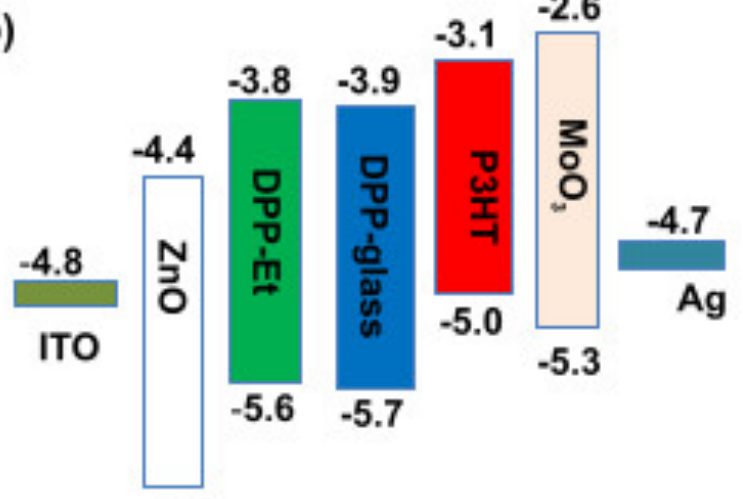

(d)

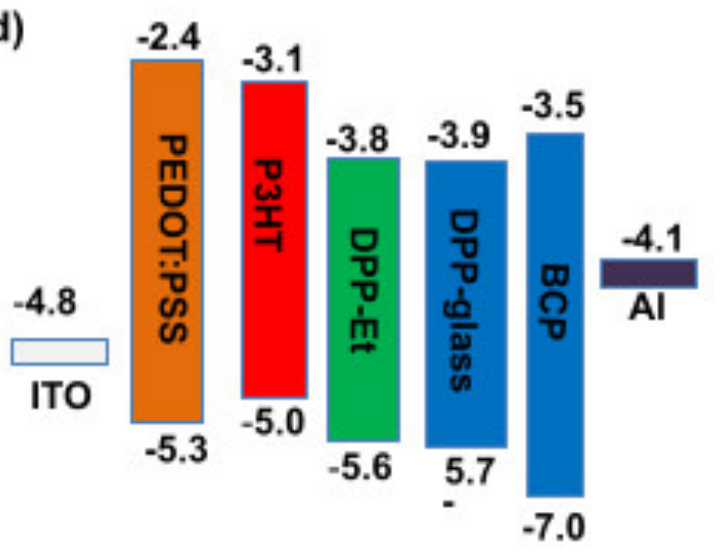

Figure 1. Device structure and energy level alignment of photovoltaic cells with DPP derivatives 5-6. (a,b) Inverted cell, and (c,d) conventional cell. 


\section{Results and Discussion}

\section{Synthesis}

It has been shown in the literature that DPP derivatives with weakly electronwithdrawing substituents show optimal performance as acceptor materials in organic PV cells, because the HOMO and LUMO levels are closer to that of the donor polymers commonly used. ${ }^{19}$ In the current case, to be able to functionalize the DPP core with a mexylaminotriazine group, active methylene derivatives constitute an appealing way to bond both moieties together, as they can easily condense with aldehydes. In particular, in the synthesis of both donor and acceptor materials for photovoltaics, dicyanovinyl or rhodanine groups are often thusly introduced to introduce strongly electron-withdrawing groups to tune the HOMO and LUMO levels. ${ }^{39,40}$ For this purpose, a mexylaminotriazine derivative with a rhodanine group (2) could be conveniently synthesized from amino precursor 1, which was previously reported, ${ }^{41}$ with $\mathrm{CS}_{2}$ and ethyl chloroacetate in the presence of base and KI (Scheme 1). ${ }^{42}$

Scheme 1. Synthesis of rhodanine glass 2.

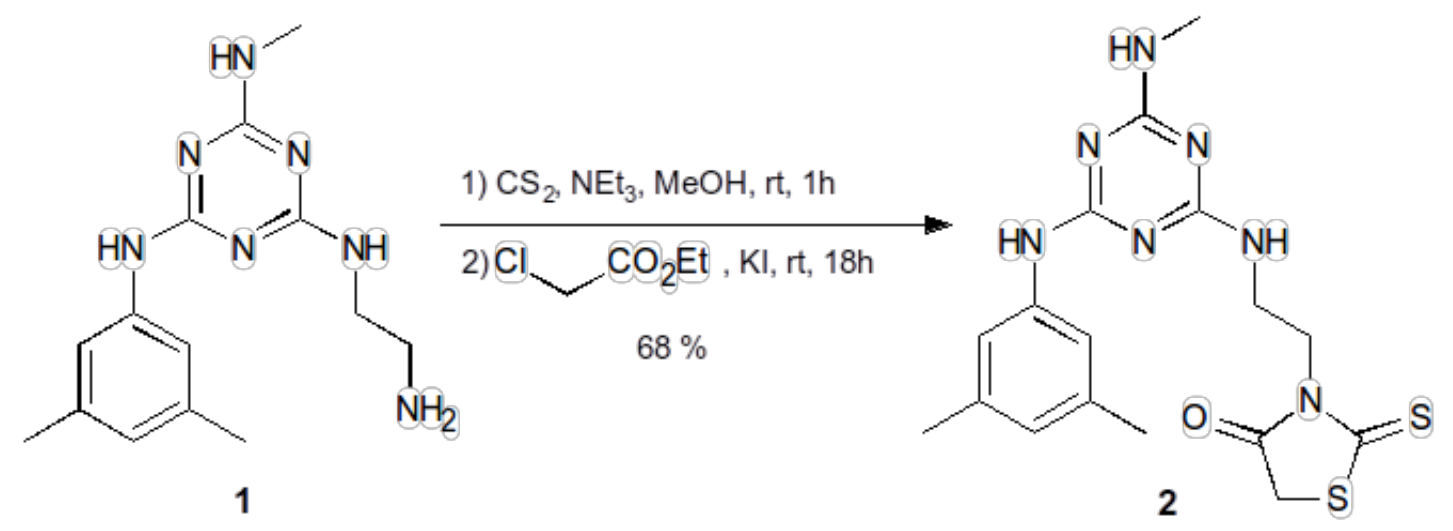

Rhodanine derivative 2 was condensed with 4-formylphenyl-substituted DPP derivative 4, which was synthesized by a Suzuki coupling between the previously reported monobrominated derivative $3^{33,38}$ and 4-formylphenylboronic acid, to give target adduct 5 (referred to as DPP-glass) in $62 \%$ yield (Scheme 2). This monosubstituted precursor was selected for two reasons: firstly, to mitigate the electron-withdrawing character of the 
methylene rhodanine adduct, and second, to conserve an appreciable solubility in a wide range of solvents, as the presence of a second triazine group is known to limit solubility to polar solvents such as THF or DMF. n-Hexyl chains were selected for the amide groups on the DPP core to minimize steric hindrance around the electroactive moiety. While branched chains result in typically higher solubility, the remote mexylaminotriazine unit also serves as solubilizing group in the present case, thereby eliminating the need for bulkier groups.

Scheme 2. Synthesis of DPP rhodanine derivatives 5-6.

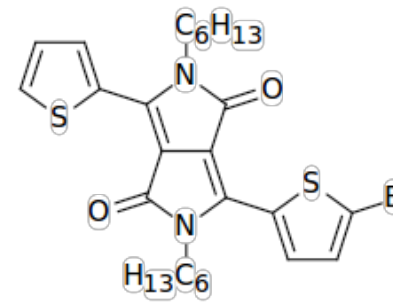

3

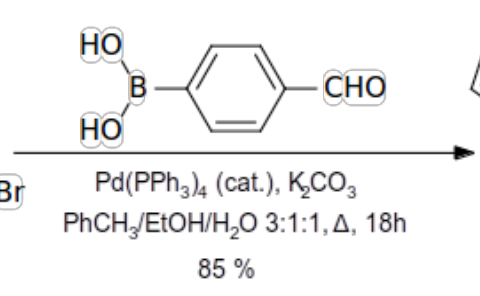

$85 \%$

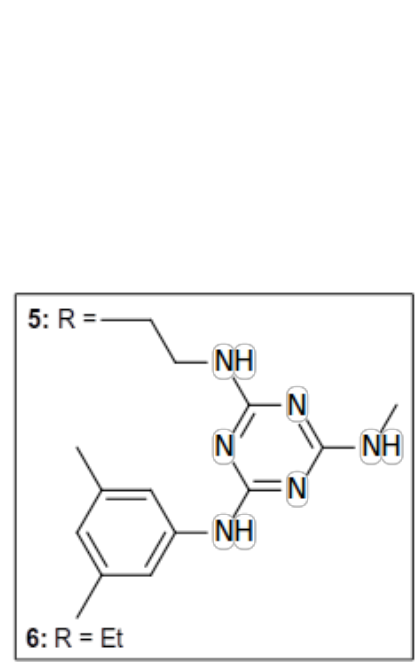

Precursor 4 could also be condensed with commercially available ethylrhodanine to yield analogue 6 (DPP-Et) which is substituted with a simple ethyl chain. While DPP-glass 5 is expected to readily form glassy phases, ethyl analogue $\mathbf{6}$ is expected to crystallize, thereby allowing a direct comparison of the photovoltaic performance of analogous acceptor materials that differ by their preferred solid-state packing. 


\section{Physical Properties}

The phase transition temperatures of rhodanine glass 2 and DPP derivatives 5-6 were probed by Differential Scanning Calorimetry (DSC). As expected, rhodanine derivative 2, like its amino precursor, readily forms glassy phases with a glass transition temperature $\left(\mathrm{T}_{\mathrm{g}}\right)$ of $76^{\circ} \mathrm{C}$, and no crystallization observed upon either prolonged standing or slow heating. Its DPP adduct 5, DPP-glass, also shares the glass-forming ability of its precursor with a $\mathrm{T}_{\mathrm{g}}$ of $89{ }^{\circ} \mathrm{C}$, and no crystallization was observed under any of the conditions used. On the other hand, ethyl-substituted DPP analogue 6 (DPP-Et) readily crystallizes, with a melting transition at $176^{\circ} \mathrm{C}$. No glass formation was observed under operating conditions. DSC curves can be found in Figure S1 (Supporting Information).

The UV-Visible absorption spectra of DPP-glass 5 and DPP-Et 6 in $\mathrm{CH}_{2} \mathrm{Cl}_{2}$ solution and as thin films spin-coated from $\mathrm{CH}_{2} \mathrm{Cl}_{2}$ are shown in Figure 2. Both compounds show two closely similar spectra with two distinct absorption bands at shorter $(\sim 432 \mathrm{~nm})$ and longer wavelengths $(\sim 575 \mathrm{~nm})$. As compounds 5-6 share the band near $575 \mathrm{~nm}$ with their precursor 4 , this band can likely be attributed to the $\pi-\pi^{*}$ transition of the DPP core, whereas the band near $430 \mathrm{~nm}$, which is absent in compound 4, originates from the rhodanine group. Both compounds show a slight red shift in thin films as compared to solution for both bands. However, the shift is slightly more pronounced for DPP-glass 5 showing stronger intermolecular interactions (i.e. $\pi$ - $\pi$ stacking) in the solid state. It is noteworthy that these materials exhibit broad absorption in the range 300-750 nm, which is ideal for enhancing light harvesting, and thus should be beneficial for photovoltaic performance. The optical band gaps estimated from the absorption edges of the thin films of DPP-glass 5 and DPP-Et 6 are $1.87 \mathrm{eV}$ and $1.85 \mathrm{eV}$ respectively. 


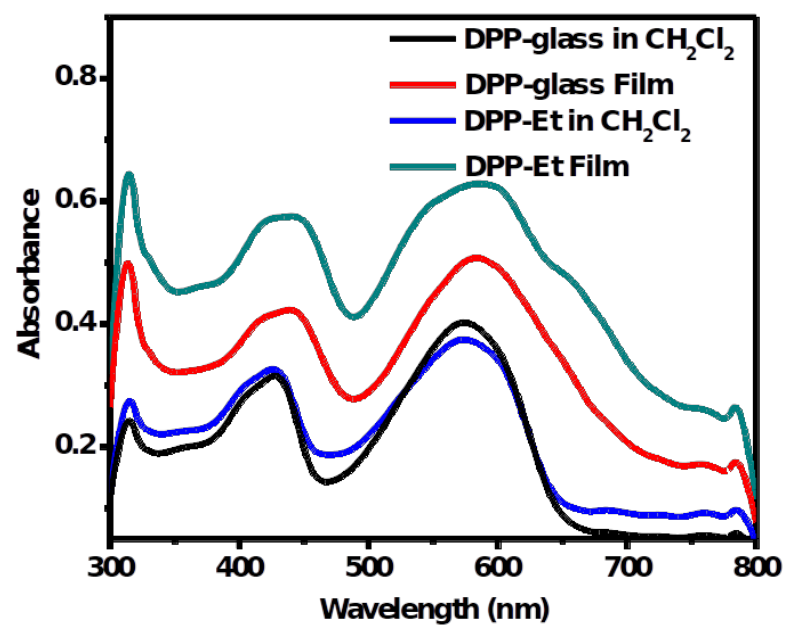

Figure 2. UV-Visible absorption spectra of diketopyrrolpyrrole (DPP) derivatives 5-6 in $0.01 \mathrm{M} \mathrm{CH}_{2} \mathrm{Cl}_{2}$ and as solid thin films.

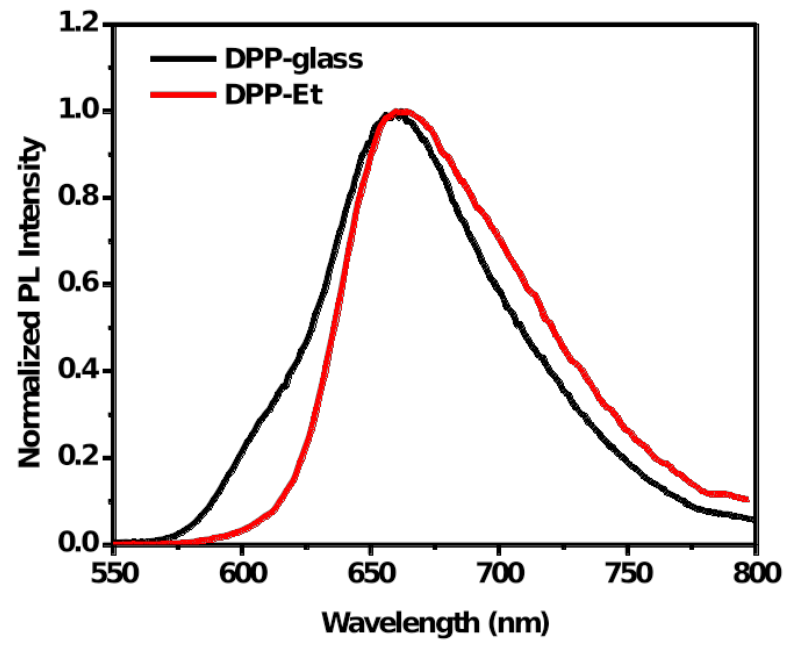

Figure 3. Normalized Fluorescence Spectra for DPP derivatives 5-6.

The emission spectra for both DPP derivatives in chlorobenzene are shown in Figure 3. These molecules exhibit a purple emission with maxima at 652 and $659 \mathrm{~nm}$ for DPPglass 5 and DPP-Et 6, respectively. DPP-glass 5 shows a slight $(\sim 7 \mathrm{~nm})$ emission blue shift as compared to Et analogue 6 due to the presence of the remote electronwithdrawing triazine ring in glass $\mathbf{5} .^{19}$

Normalized UV-Visible spectra of thin films of blends of P3HT with DPP derivatives 5-6 in 1:1 ratios processed by spin-coating from chlorobenzene solution are shown in Figure 4. The blends of both derivatives with P3HT absorb strongly in the UV and visible range 
from $350 \mathrm{~nm}$ to $700 \mathrm{~nm}$ showing the homogenous mixing of both components. The blends of P3HT/DPP-glass 5 show two bands at $440 \mathrm{~nm}$ and $560 \mathrm{~nm}$ whereas the blend of P3HT/DPP-Et 6 shows two bands at 440 at $520 \mathrm{~nm}$. The fact that the P3HT blend with DPP-glass shows a red-shifted band compared to the blend with DPP-Et suggests a higher degree of $\pi$ - $\pi$ stacking throughout the material.

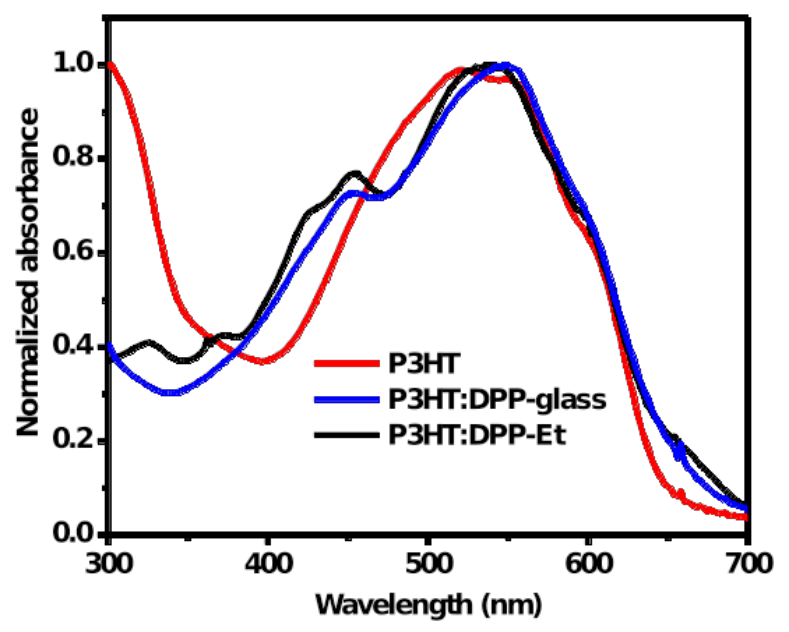

Figure 4. Normalized UV- Visible spectra for films of P3HT and blends with DPP derivatives 5-6 deposited by spin-coating from chlorobenzene solution.

\subsection{Electrochemical analysis by Cyclic Voltammetry}

The reduction potentials of DPP-rhodanine derivatives 5-6 were investigated by cyclic voltammetry (CV) with a standard three-electrode electrochemical cell in an anhydrous acetonitrile solution at ambient temperature with $0.1 \mathrm{M}$ tetrabutylammonium hexafluorophosphate $\left(\mathrm{Bu}_{4} \mathrm{NPF}_{6}\right)$ as a supporting electrolyte and ferrocene as internal standard. The cyclovoltammograms of compounds 5-6 are shown in Figure S2 (Supporting Information). In both cases, a half reduction signal was measured because DPP-rhodanine derivatives 5-6, as electron acceptors, display very weak oxidation signals. The values for the reduction potentials are listed in Table 1. From the reduction potentials, the LUMO energy levels for DPP-rhodanine derivatives 5-6 were calculated by comparison to ferrocene $(-4.8 \mathrm{eV})$. From the LUMO energy levels and the optical band gap, the HOMO levels of DPP-glass derivatives were calculated, and are listed in Table 1. The HOMO and LUMO energy levels for compounds 5-6 are lower than 
published values for other previously reported DPP derivatives: the HOMO and LUMO energy levels for DPP-rhodanine derivatives 5-6 are close to -5.7 and $-3.9 \mathrm{eV}$ respectively, whereas typical HOMO levels for diaryl-DPP derivatives range from -5.1 to $-5.4 \mathrm{eV}$ while their LUMO levels range from -3.3 to $-3.5 \mathrm{eV} .{ }^{43}$ While it has been shown that groups that are too electron-withdrawing $\left(\mathrm{NO}_{2}, \mathrm{CN}\right)$ lower device efficiency, these results were reported for symmetrically substituted diaryl-DPP derivatives, and it is possible that the presence of only one electron-withdrawing group in DPP-rhodanine derivatives 5-6 mitigates this effect.

Table 1. Reduction potentials and HOMO and LUMO energy levels for DPP derivatives 5-6.

\begin{tabular}{llllll}
\hline DPP & $\begin{array}{l}\text { Reduction } \\
\text { Potential }\end{array}$ & E $_{\text {red(onset) }}$ & LUMO & $\begin{array}{l}\text { Optical } \\
\text { gap }\end{array}$ & HOMO \\
\hline DPP-glass (5) & -0.43 & -0.93 & -3.87 & 1.87 & -5.74 \\
& & & & & \\
\hline DPP-Et (6) & -0.48 & -0.98 & -3.82 & 1.85 & -5.67
\end{tabular}

\subsection{XRD for blends of P3HT \& DPP-rhodanine derivatives}

X-ray diffraction (XRD) analyses were performed in order to understand the packing behavior and crystallinity of thin films. The films were prepared by spin-coating DPP derivatives 5-6 and their respective blends with $\mathrm{P} 3 \mathrm{HT}$ in a 1:1 ratio after annealing at $100{ }^{\circ} \mathrm{C}$ for 10 minutes. The XRD patterns for the pristine films of DPP derivatives 5-6 and their blends with P3HT are shown in Figure 5. As-deposited films were largely amorphous, whereas annealing at $100{ }^{\circ} \mathrm{C}$ caused DPP-Et 6 to crystallize, resulting in primary peaks at $2 \theta=6.2$ and $10.96^{\circ}$, showing a polycrystalline arrangement as reported in the literature. ${ }^{32}$

For all blends with $\mathrm{P} 3 \mathrm{HT}$, one major diffraction peak corresponding to the [100] plane was observed $2 \theta=5-7^{\circ}$ ), showing the first-order structure of P3HT with a $d$ spacing of $1.7 \mathrm{~nm} .{ }^{44,} 45$ Pristine films of P3HT:DPP blends exhibit weak XRD peak intensity as compared to annealed samples. The weak intensity observed for pristine films is due to 
the low-order structure of P3HT. Thermal annealing at $100{ }^{\circ} \mathrm{C}$ causes the side chains of P3HT to pack in a more ordered fashion, leading to an increase in crystallinity. However, the crystalline peak of DPP-Et in the blend disappear suggesting complete inhibition of DPP-Et crystallization in the polymer blend. It could be due to the fact that polymer might hinder the crystallization of DPP-Et in the blend.
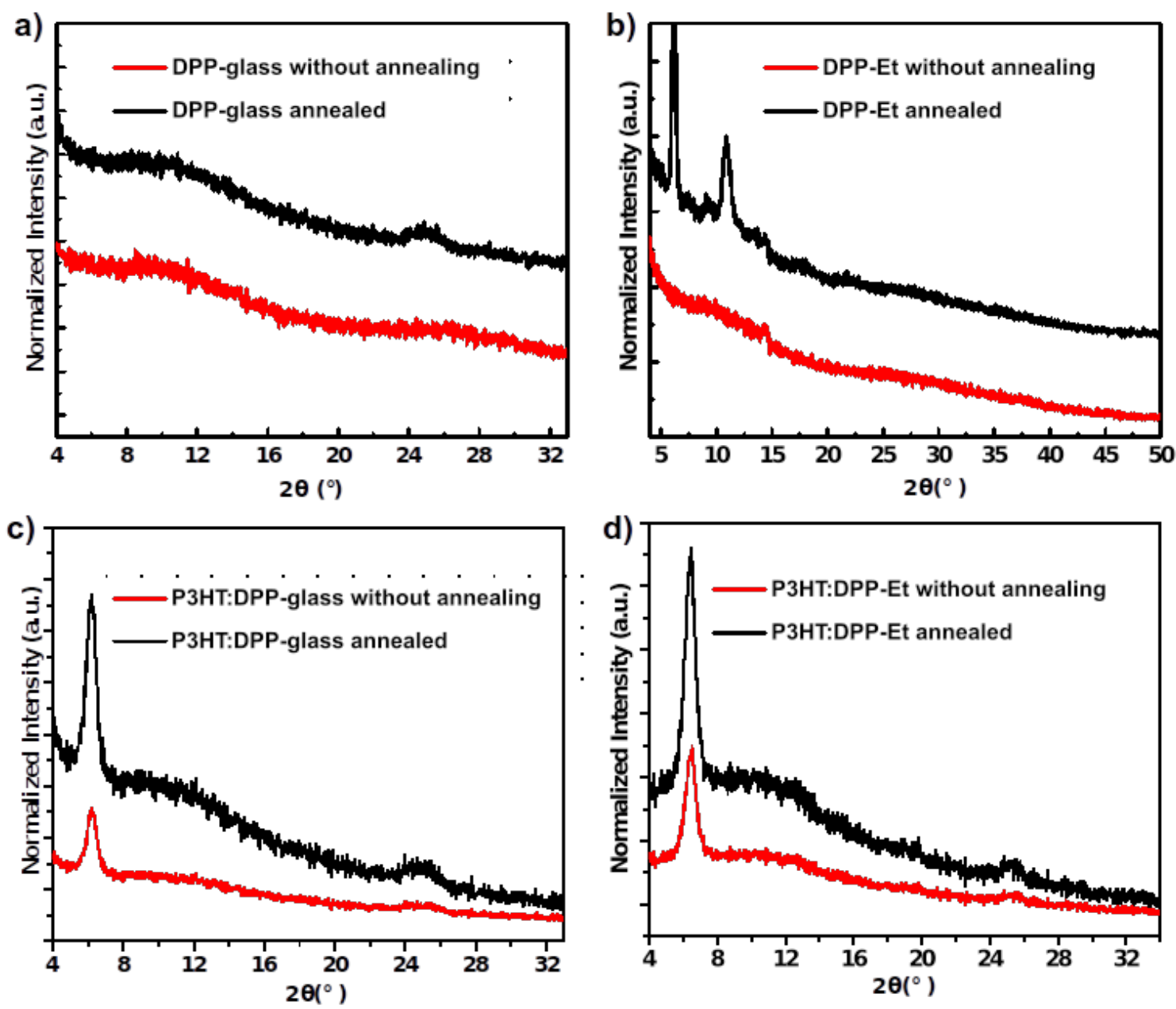

Figure 5. XRD for films of DPP derivatives 5-6 and their blends with P3HT deposited by spin-coating from chlorobenzene solution: (a) DPP-glass (5) (b) DPP-Et (6) (c) P3HT:DPP-glass and (d) P3HT:DPP-Et. Films were annealed at $100{ }^{\circ} \mathrm{C}$ for 10 minutes. 


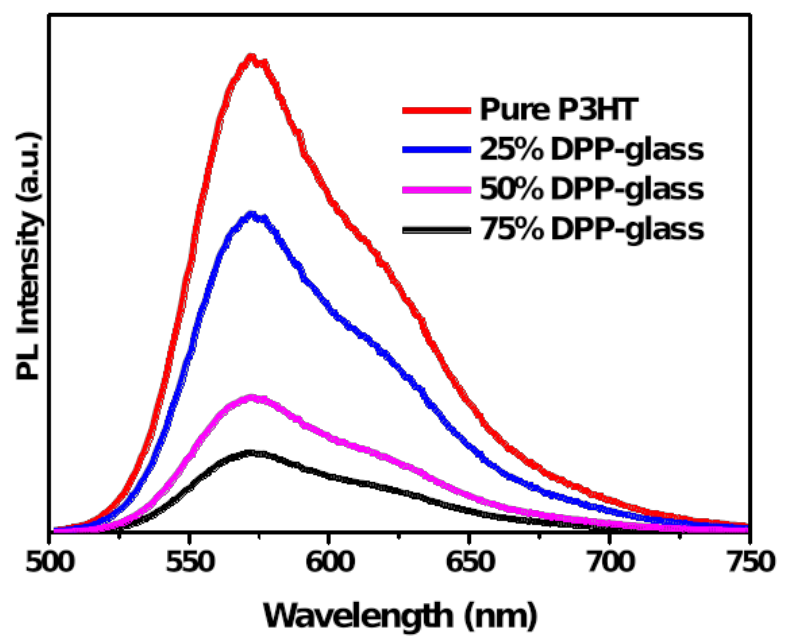

Figure 6. Photoluminescence quenching of P3HT by different concentrations of DPPglass 5 .

The electron acceptor behavior of these DPP derivatives was further studied by photoluminescence (PL) quenching, which is a characteristic behavior of acceptor materials in photovoltaic applications. For an efficient photovoltaic device, fast transfer of photoinduced charges from the donor to the acceptor is essential. ${ }^{46}$ If the electron is not transferred within a few femtoseconds in the working device, the photo-generated exciton will decay to ground state, emitting photoluminescence and resulting in poor device efficiency. PL quenching is thus attributed to electron transfer from the photoexcited donor to the acceptor, as observed by Nikitenko et al. in a study of the photoluminescence quenching of MDMO-PPV by fullerene derivatives. ${ }^{47}$ Thus, a high PL quenching of donor-acceptor blends is therefore expected for high performance devices. The photoluminescence quenching of DPP-rhodanine derivatives 5-6 was studied with a blend of P3HT with DPP-glass 5 as representative compound. The PL spectra are depicted in Figure 6. From Figure 6, it is observed that as the concentration of DPP-glass 5 is increased, the PL intensity decreases sharply up to a DPP-glass concentration of $50 \%$ weight ratio, at which point PL intensity continues decreasing at a slower rate as the concentration of DPP-glass is further increased.

\subsection{Atomic Force Microscopy (AFM)}


The surface morphology of the films of DPP derivatives 5-6 and their respective blends with P3HT was studied by AFM. The surface topographic images for films of DPP derivatives 5-6 and their 1:1 blends with P3HT after annealing at $100{ }^{\circ} \mathrm{C}$ for 10 minutes are shown in Figure 7. The pristine DPP-glass film shows a smooth surface with a root mean square (RMS) roughness of $1.1 \mathrm{~nm}$, whereas the DPP-Et film shows a grainy topology with a RMS roughness of $16.1 \mathrm{~nm}$. While the surface of the film of the P3HT/DPP-glass blend shows a patchwork of crystalline domains attributable to P3HT, the film is relatively smooth with a RMS roughness of $2.0 \mathrm{~nm}$. In contrast, the film of the P3HT/DPP-Et blend, while not as rough as the pure DPP-Et film, also shows a grainy surface with a RMS roughness of $8.9 \mathrm{~nm}$. DPP-glass, because of its amorphous nature, forms films that are topologically smoother than that of DPP-Et, even in the presence of a crystalline component (P3HT). As surface topology has been shown to be important for optimal cell performance ${ }^{48,49}$ the fact that DPP-glass forms smoother films is expected to counterbalance the more regular packing of crystalline DPP-Et.
a) $0 \mu \mathrm{m}$
5
b)

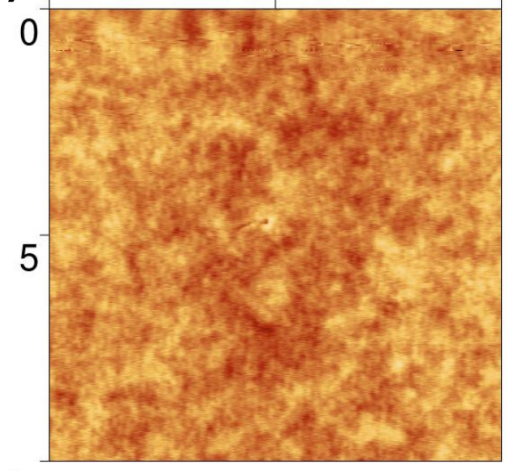
$14.7 \mathrm{n}$
-12.0
10.0
8.0
6.0
4.0
0.0
b) $0 \mu \mathrm{m}$
5

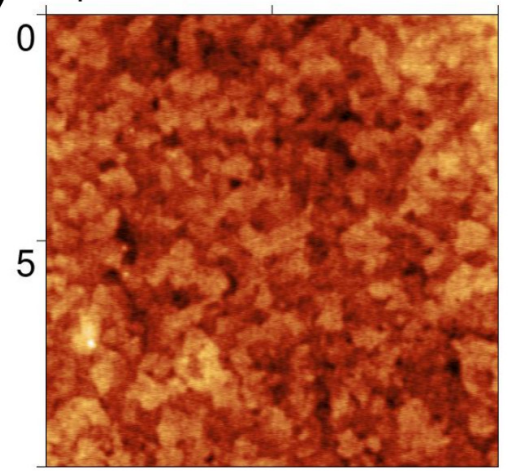
$20.0 \mathrm{~nm}$
c) $0 \mu \mathrm{m}$
5
d) $0 \mu \mathrm{m}$
5
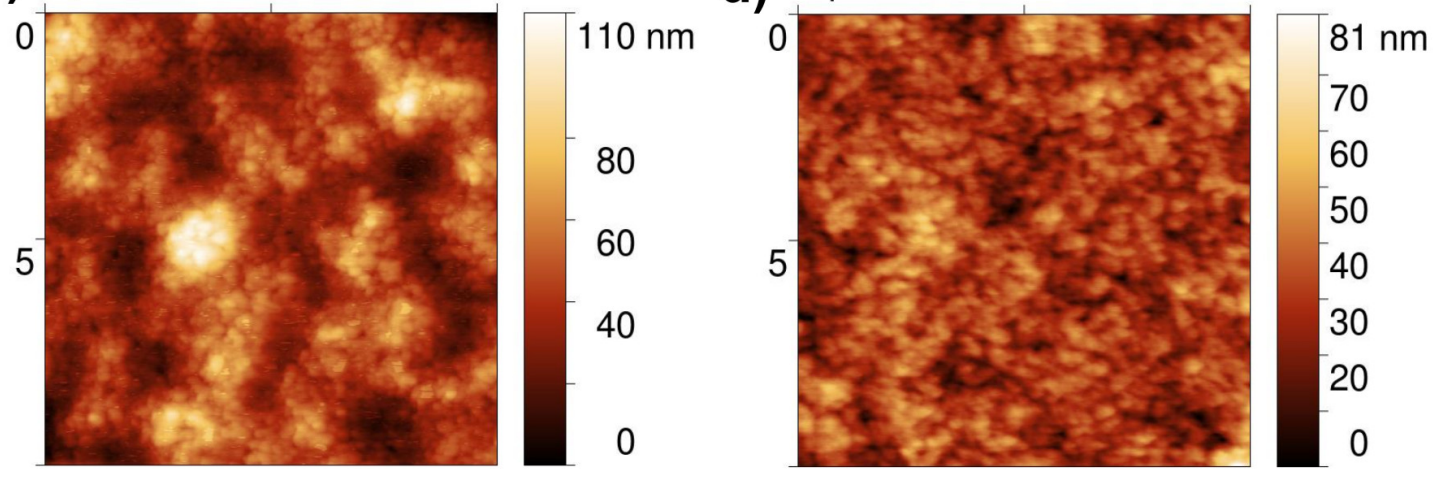
Figure 7. AFM topographic images $(10 \mu \mathrm{m} \times 10 \mu \mathrm{m})$ for films of DPP derivatives 5-6 and their respective blends with $\mathrm{P} 3 \mathrm{HT}$ in 1:1 weight ratio spin-coated from chlorobenzene after annealing at $100{ }^{\circ} \mathrm{C}$ for 10 minutes. (a) DPP-glass (5) (b) P3HT/DPP-glass (c) DPP-Et (6) (d) P3HT/DPP-Et.

\subsection{Mobility Measurement from SCLC method}

High electron mobility is a basic requirement for effective photovoltaic active materials to ensure effective charge carrier transport to the electrodes and reduce photocurrent loss in organic PV cells. The electron mobility of DPP derivatives 5-6 was experimentally calculated from the IV characteristics of diodes of configuration $\mathrm{ITO} / \mathrm{ZnO} / \mathrm{DPP} / \mathrm{MoO}_{3} / \mathrm{Ag}$. Electron mobility was calculated using the Mott-Gurney spacecharge-limited current (SCLC) equation..$^{50}$ The current-voltage curves of the diodes were fitted with the SCLC model and the mobility was calculated from the intercept of the linear fit of the SCLC region with the experimentally measured capacitance and thickness of the diodes. The electron mobility was calculated, and the results are shown below in Table 2 (details about the calculations can be found in Supporting Information and additional data is listed in Table S1).

Table 2. Electron mobility values for DPP derivatives 5-6.

DPP derivative $\quad$ Mobility $\left(\mathrm{cm}^{2} \mathrm{~V}^{-1} \mathrm{~s}^{-1}\right)$

DPP-glass (5) $1.46 \times 10^{-5} \pm 0.10 \times 10^{-5}$

DPP-Et (6) $5.28 \times 10^{-6} \pm 0.12 \times 10^{-6}$

From Table 2, it can be observed that while both DPP-glass 5 and DPP-Et $\mathbf{6}$ show modest mobilities in the $10^{-6}-10^{-5}$ range, unexpectedly, DPP-glass shows a mobility about 2.7 times higher than its crystalline counterpart DPP-Et, showing relatively more efficient electron transport. This may be a surprising observation because crystalline materials typically show mobilities orders of magnitude higher than amorphous materials because of an optimal solid-state packing between molecules. ${ }^{51,52}$ However, a high number of grain boundaries and defects can drastically reduce mobility in polycrystalline thin films. ${ }^{53,54}$ In the current case, it is likely that because DPP-Et yields rougher films with 
grainy surface topologies, the higher defect density could cause charge recombination, which is detrimental for electron mobility. This unbalanced charge accumulation and low mobility leads to poor fill factor and PCE of DPP-Et. ${ }^{55}$

\subsection{Current-Voltage (I-V) Characteristics of P3HT/DPP devices.}

Solution processed organic photovoltaic cells with an inverted structure were fabricated using P3HT as donor and DPP derivatives (5-6) as acceptors in blend ratios of 1:2, 1:1 and 2:1 by mass. The blends were deposited by spin-coating from chlorobenzene solution on ITO substrates coated with $30 \mathrm{~nm}$ of $\mathrm{ZnO}$. After annealing at $100{ }^{\circ} \mathrm{C}$ for 10 minutes, the active layers were then coated with a layer of $6 \mathrm{~nm} \mathrm{MoO}_{3}$ and an $80 \mathrm{~nm} \mathrm{Ag}$ electrode, to yield devices with structure ITO/ZnO/P3HT:DPP/MoO $/$ Ag. Photovoltaic measurements were performed in ambient conditions using a Xenon source with an irradiance of $100 \mathrm{mWcm}^{-2}$ calibrated with an AM 1.5 solar simulator. The devices were optimized with different donor/acceptor compositions and different annealing temperatures. The optimal performance was obtained with devices with a 1:2 P3HT/DPP blend ratio and an annealing temperature of $100{ }^{\circ} \mathrm{C}$. The current-voltage characteristics in the dark and under illumination for devices with P3HT and DPP derivatives 5-6 with blend ratios 1:2, 1:1 and 2:1 are shown in Figures 8-9. The power conversion efficiency $(\eta)$ of the devices was calculated from the open-circuit voltage $\left(V_{o c}\right)$, short-circuit current density $\left(\mathrm{J}_{\mathrm{sc}}\right)$ and fill factor $(\mathrm{FF})$ values with the following equation: PCE $(\eta)=$ $J_{s c} \times V_{o c} \times F F / P_{i n}$, where $P_{\text {in }}$ represents the power of incident light $\left(\mathrm{mWcm}^{-2}\right)$. The fill factor was calculated from the open-circuit voltage $\left(\mathrm{V}_{\mathrm{oc}}\right)$, short-circuit current $\mathrm{I}_{\mathrm{sc}}$, and maximum power $\left(\mathrm{P}_{\max }\right)$ values according to the following equation: $\mathrm{FF}=\mathrm{P}_{\max } / \mathrm{J}_{\mathrm{sc}} \times \mathrm{V}_{\mathrm{oc}}=$ $\mathrm{J}_{\max } \times \mathrm{V}_{\max } / J_{\mathrm{sc}} \times \mathrm{V}_{\text {oc }}$, where $\mathrm{J}_{\max }$ and $\mathrm{V}_{\max }$ are the current density and voltage at maximum

power, respectively. The photovoltaic parameters of the inverted devices fabricated with P3HT and DPP derivatives 5-6 were corrected according to the calibrated solar simulator and are reported in Table 3. The details of the correction are shown in Table S1 (Supporting Information). The inverted devices fabricated with DPP derivatives e-f showed power conversion efficiencies ranging from 0.34 to $1.59 \%$. From the currentvoltage characteristics in the dark shown in Figure 8a, it can be observed that the annealed device with DPP-glass 5 in a 1:2 ratio shows the lowest leakage current in 
reverse bias with the highest shunt resistance showing the best performance, whereas the un-annealed 1:2 device with DPP-Et 6 shows the highest leakage current showing poor performance. The devices with a 1:2 P3HT/DPP ratio show overall the highest performance, with efficiencies for annealed devices ranging from 1.01 to $1.59 \%$, in comparison to $0.35-0.62 \%$ for $1: 1$ and $0.34-0.77 \%$ for $2: 1$ (current-voltage curves for 1:1 and 2:1 devices are shown in Figurs S3, Supporting Information). The I-V curves under illumination shown in Figure $8 \mathrm{~b}$ demonstrate that the devices with DPP derivatives 5-6 in 1:2 ratio show that annealing improved open-circuit voltage and efficiency by 15 to $30 \%$, while open-circuit voltage and fill factor were largely unaffected. The inverted device with amorphous DPP-glass showed the highest efficiency $(1.57 \%)$, with a shortcircuit current of $2.99 \mathrm{mAcm}^{-2}$, an open-circuit voltage of $0.81 \mathrm{~V}$ and a fill factor of 0.62 . In contrast, the device with crystalline DPP-Et shows an efficiency $1.01 \%$ with a shortcircuit current of $2.04 \mathrm{mAcm}^{-2}$, an open-circuit voltage of $0.77 \mathrm{~V}$ and a fill factor of 0.63 . Regular devices with structure ITO/PEDOT: PSS/P3HT: DPP/BCP/Al were fabricated with the optimal 1:2 blend ratio, and the current-voltage curves in both the absence and presence of light are displayed in Figure 9. Again, the curve in the dark (Figure 9a) shows that the device with DPP-glass shows lower leakage current as compared with the device with DPP-Et, showing superior film forming characteristics and higher PV performance. The photovoltaic parameters were calculated from the data extracted from the curves under illumination and corrected according to calibrated data from a solar simulator, and are listed in Table 4. The power conversion efficiencies obtained with this cell structure $(1.12-2.54 \%)$ were significantly higher than those obtained with the inverted devices. Again, the annealed device with DPP-glass showed the highest efficiency (2.54\%), while the similar device using DPP-Et showed an efficiency of $1.60 \%$.

In the current case, it is clear that amorphous DPP-glass yields PV cells that show efficiencies approximately $50 \%$ higher than its crystalline counterpart, DPP-Et. While the open-circuit voltage and fill factor of the devices are roughly similar independently of the DPP derivative used, the short-circuit current is 20 to $40 \%$ higher with DPP-glass. The higher efficiency of DPP-glass is likely to be attributed to the smoother surface morphology of the film, resulting in increased electron mobility and reduced series resistance. 

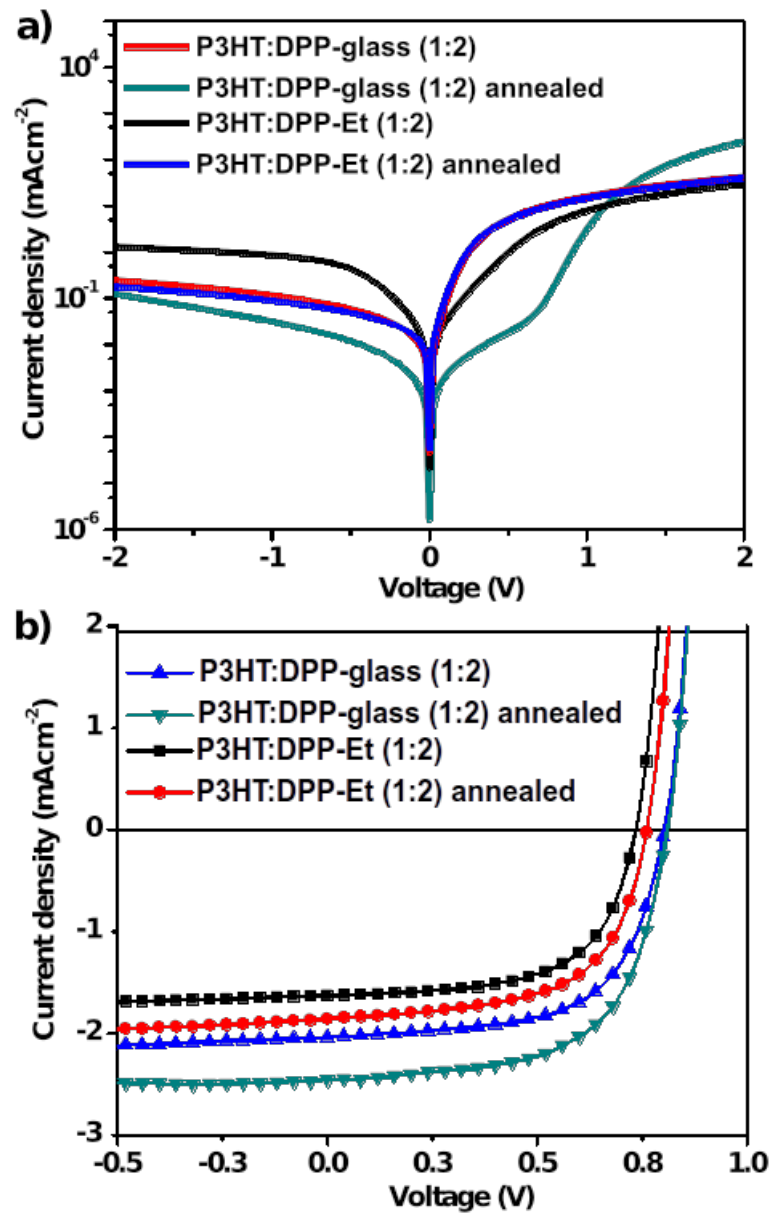

Figure 8. Current-voltage characteristics of ITO/ZnO/P3HT:DPP/MoO $/ \mathrm{Ag}$ devices with a 1:2 P3HT/DPP ratio (a) in the dark, and (b) under illumination with an irradiance of $100 \mathrm{~mW} \mathrm{~cm}^{-2}$.

Table 3. Photovoltaic parameters of ITO/ZnO/P3HT:DPP (1:2)/ $\mathrm{MoO}_{3} / \mathrm{Ag}$ devices with DPP derivatives 5-6 under illumination with an intensity of $100 \mathrm{mWcm}^{-2}$

\begin{tabular}{lllllll}
\hline DPP & $\begin{array}{l}\text { P3HT:DPP } \\
\text { Ratio }\end{array}$ & $\begin{array}{l}\text { Thermal } \\
\text { Annealing }\end{array}$ & $\mathbf{J}_{\text {sc }}\left(\mathbf{m A c m}^{-2}\right)$ & $\mathbf{V}_{\text {oc }}(\mathbf{V})$ & FF & PCE (\%) \\
\hline DPP-glass & $1: 2$ & no & 2.24 & 0.81 & 0.67 & $1.23 \pm 0.03$ \\
\hline DPP-glass & $1: 2$ & $100{ }^{\circ} \mathrm{C}$ & 2.99 & 0.81 & 0.62 & $1.57 \pm 0.04$ \\
& & & & & & \\
\hline
\end{tabular}




\begin{tabular}{lllllll}
\hline DPP-Et & $1: 2$ & no & 1.79 & 0.75 & 0.62 & $0.84 \pm 0.02$ \\
\hline DPP-Et & $1: 2$ & $100^{\circ} \mathrm{C}$ & 2.04 & 0.77 & 0.63 & $1.01 \pm 0.01$ \\
\hline DPP-glass & $2: 1$ & $100^{\circ} \mathrm{C}$ & 1.62 & 0.73 & 0.64 & $0.77 \pm 0.03$ \\
\hline DPP-Et & $2: 1$ & $100^{\circ} \mathrm{C}$ & & & & \\
\hline DPP-glass & $1: 1$ & $100^{\circ} \mathrm{C}$ & 2.12 & 0.74 & 0.38 & $0.62 \pm 0.01$ \\
\hline DPP-Et & $1: 1$ & $100^{\circ} \mathrm{C}$ & 1.09 & 0.73 & 0.44 & $0.35 \pm 0.13$ \\
\hline
\end{tabular}
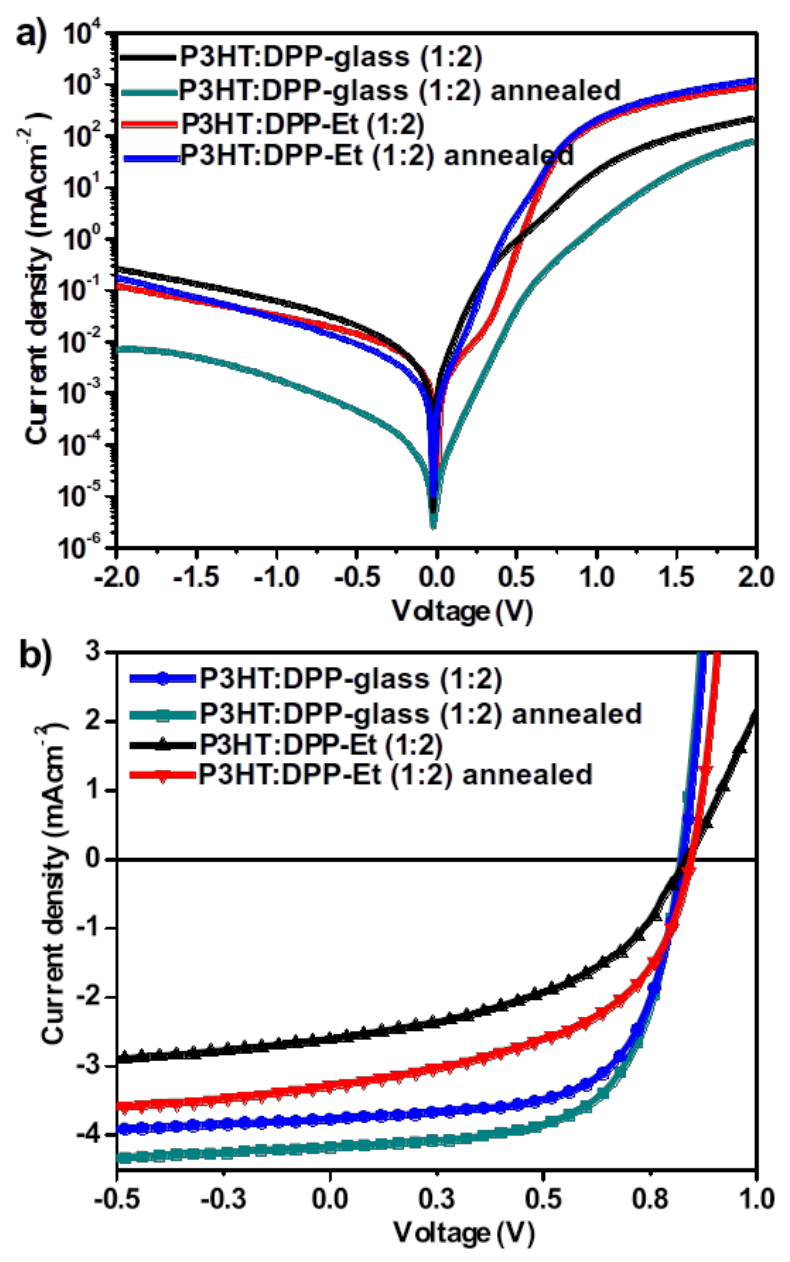
Figure 9 Current-voltage characteristics of ITO/PEDOT:PSS/P3HT:DPP(1:2)/BCP/A1 devices (a) in the dark, and (b) under illumination with an intensity of $100 \mathrm{~mW} \mathrm{~cm}^{-2}$.

Table 4. Photovoltaic parameters of ITO/PEDOT:PSS/P3HT:DPP(1:2)/BCP/Al devices with DPP derivatives 1-2 under illumination with intensity of $100 \mathrm{mWcm}^{-2}$.

\begin{tabular}{lllllll}
\hline DPP & $\begin{array}{l}\text { P3HT:DPP } \\
\text { Ratio }\end{array}$ & $\begin{array}{l}\text { Thermal } \\
\text { Annealing }\end{array}$ & $\mathbf{J}_{\text {sc }}\left(\mathbf{m A c m}^{-2}\right)$ & $\mathbf{V}_{\text {oc }}(\mathbf{V})$ & FF & PCE (\%) \\
\hline DPP-glass & $1: 2$ & no & 4.13 & 0.83 & 0.66 & $2.26 \pm 0.05$ \\
\hline DPP-glass & $1: 2$ & $100{ }^{\circ} \mathrm{C}$ & 4.58 & 0.83 & 0.67 & $2.54 \pm 0.01$ \\
\hline DPP-Et & $1: 2$ & no & 2.86 & 0.84 & 0.47 & $1.12 \pm 0.03$ \\
\hline DPP-Et & $1: 2$ & $100{ }^{\circ} \mathrm{C}$ & 3.60 & 0.84 & 0.53 & $1.60 \pm 0.02$
\end{tabular}

\section{Conclusion}

In conclusion, amorphous and crystalline diketopyrrolpyrrole (DPP) based small molecules were synthesized and tested as acceptor materials in bulk heterojunction photovoltaic cells with $\mathrm{P} 3 \mathrm{HT}$ as donor. The devices were fabricated using different P3HT/DPP blend compositions and different device structures, and power conversion efficiencies ranging from 0.34 to $2.54 \%$ were obtained. The device with amorphous DPP-glass consistently showed higher efficiencies than its crystalline counterpart, with a maximum efficiency of $2.54 \%$, which is close to the highest value reported for a DPPbased small-molecule acceptor with P3HT as donor (3\%). In contrast, the highest efficiency measured using crystalline DPP-Et is $1.60 \%$. The higher efficiency of amorphous DPP-glass is attributed to a smoother surface morphology and a lower defect density, resulting in higher electron mobility across the interface and reduced series resistance. These results clearly show that glass-forming small-molecule acceptors are appealing because they can be easily processed from solution to form thin films with a very consistent morphology with low roughness and few defects, which allows for highperformance devices with minimal screening of processing conditions. This approach has 
shown promise for the development of small-molecule materials for organic photovoltaics and will be studied further in future work.

\section{Acknowledgements}

Research at Queen's was supported by the National Science and Engineering Research Council of Canada (NSERC) Discovery Grants program (RGPIN-2015-05485) and CREATE program (Novel Chiral Materials: An International Effort in Research and Education). Research at RMCC was supported by the Canadian Defence Academic Research Program (CDARP) from RMC. We would also like to thank Dr. Philippe Venne (Université de Sherbrooke) for mass spectrometry analyses.

\section{References}

1. L. Dou, J. You, Z. Hong, Z. Xu, G. Li, R. A. Street and Y. Yang, Advanced materials, 2013, 25, 6642-6671.

2. B. Gholamkhass, N. M. Kiasari and P. Servati, Organic Electronics, 2012, 13, 945-953.

3. S. K. Hau, H.-L. Yip and A. K. Y. Jen, Polymer Reviews, 2010, 50, 474-510.

4. D. W. Pathak, T. ; Adhikari,T. ; Nunzi, J.M., Synthetic Metals, 2015, 199, 87-92.

5. T. Adhikari, M. Shahiduzzaman, K. Yamamoto, O. Lebel and J.-M. Nunzi, Solar Energy Materials and Solar Cells, 2017, 160, 294-300.

6. B. Sambathkumar, P. S. V. Kumar, K. Saurav, S. S. K. Iyer, V. Subramanian and N. Somanathan, New J. Chem., 2016, 40, 3803-3811.

7. S.-H. Liao, H.-J. Jhuo, P.-N. Yeh, Y.-S. Cheng, Y.-L. Li, Y.-H. Lee, S. Sharma and S.-A. Chen, Scientific reports, 2014, 4, 6813.

8. C. A. Wolden, J. Kurtin, J. B. Baxter, I. Repins, S. E. Shaheen, J. T. Torvik, A. A. Rockett, V. M. Fthenakis and E. S. Aydil, Journal of Vacuum Science \& Technology A: Vacuum, Surfaces, and Films, 2011, 29, 030801.

9. Y. Zhou, L. Ding, K. Shi, Y. Z. Dai, N. Ai, J. Wang and J. Pei, Advanced materials, 2012, 24, 957-961. 
10. G. Li, R. Zhu and Y. Yang, Nature Photonics, 2012, 6, 153-161.

11. K. Cnops, B. P. Rand, D. Cheyns, B. Verreet, M. A. Empl and P. Heremans, Nature communications, 2014, 5, 3406.

12. E. Kozma, D. Kotowski, S. Luzzati, M. Catellani, F. Bertini, A. Famulari and G. Raos, RSC Advances, 2013, 3, 9185.

13. E. Kozma and M. Catellani, Dyes and Pigments, 2013, 98, 160-179.

14. S. C. Veenstra, J. Loos and J. M. Kroon, Progress in Photovoltaics: Research and Applications, 2007, 15, 727-740.

15. V. Kamm, G. Battagliarin, I. A. Howard, W. Pisula, A. Mavrinskiy, C. Li, K. Müllen and F. Laquai, Advanced Energy Materials, 2011, 1, 297-302.

16. W. S. Shin, H.-H. Jeong, M.-K. Kim, S.-H. Jin, M.-R. Kim, J.-K. Lee, J. W. Lee and Y.-S. Gal, Journal of Materials Chemistry, 2006, 16, 384.

17. C.-Z. Li, H.-L. Yip and A. K. Y. Jen, Journal of Materials Chemistry, 2012, 22, 4161.

18. F. Fernández-Lázaro, N. Zink-Lorre and Á. Sastre-Santos, J. Mater. Chem. A, 2016, 4, 9336-9346.

19. P. Sonar, G.-M. Ng, T. T. Lin, A. Dodabalapur and Z.-K. Chen, Journal of Materials Chemistry, 2010, 20, 3626.

20. J. T. Bloking, X. Han, A. T. Higgs, J. P. Kastrop, L. Pandey, J. E. Norton, C. Risko, C. E. Chen, J.-L. Brédas, M. D. McGehee and A. Sellinger, Chemistry of Materials, 2011, 23, 5484-5490.

21. Q. Yan, Y. Zhou, Y.-Q. Zheng, J. Pei and D. Zhao, Chemical Science, 2013, 4, 4389.

22. S. D. Collins, N. A. Ran, M. C. Heiber and T.-Q. Nguyen, Advanced Energy Materials, 2017, DOI: 10.1002/aenm.201602242, 1602242.

23. R. Steim, F. R. Kogler and C. J. Brabec, Journal of Materials Chemistry, 2010, 20, 2499-2512.

24. C. A. Angell, Science, 1995, 267, 1924.

25. P. Strohriegl and J. V. Grazulevicius, Advanced materials, 2002, 14, 1439-1452.

26. M. Y. Khilji, M. Z. Khan and A. Qayyum, 1999. 
27. E. Ishow, B. Lebon, Y. He, X. Wang, L. Bouteiller, L. Galmiche and K. Nakatani, Chemistry of materials, 2006, 18, 1261-1267.

28. V. Vaitkeviciene, J. V. Grazulevicius, V. Peciuraite, S. Grigalevicius and V. Jankauskas, Molecular Crystals and Liquid Crystals, 2007, 468, 141/[493]$150 /[502]$.

29. J. D. Wuest and O. Lebel, Tetrahedron, 2009, 65, 7393-7402.

30. R. N. Eren, A. Plante, A. Meunier, A. Laventure, Y. Huang, J. G. Briard, K. J. Creber, C. Pellerin, A. Soldera and O. Lebel, Tetrahedron, 2012, 68, 1013010144.

31. A. Laventure, A. Soldera, C. Pellerin and O. Lebel, New Journal of Chemistry, 2013, 37, 3881 .

32. T. Adhikari, Z. Ghoshouni Rahami, J.-M. Nunzi and O. Lebel, Organic Electronics, 2016, 34, 146-156.

33. R. Kirby, R. G. Sabat, J.-M. Nunzi and O. Lebel, J. Mater. Chem. C, 2014, 2, 841-847.

34. K. Piskorz, J. M. Dust, E. Buncel, O. Lebel and J.-M. Nunzi, New Journal of Chemistry, 2017.

35. Y. Lin, L. Ma, Y. Li, Y. Liu, D. Zhu and X. Zhan, Advanced Energy Materials, 2013, 3, 1166-1170.

36. D. Yu, Y. Liu, M. Xiao, Q. Fan, W. Su, X. Li, H. Tan, Y. Wang, R. Yang and W. Zhu, Dyes and Pigments, 2016, 125, 151-158.

37. F. E. Ala'a, J.-P. Sun, I. G. Hill and G. C. Welch, Journal of Materials Chemistry $A, 2014,2,1201-1213$.

38. B. Walker, J. Liu, C. Kim, G. C. Welch, J. K. Park, J. Lin, P. Zalar, C. M. Proctor, J. H. Seo and G. C. Bazan, Energy \& Environmental Science, 2013, 6, 952-962.

39. Y. H. Chen, L. Y. Lin, C. W. Lu, F. Lin, Z. Y. Huang, H. W. Lin, P. H. Wang, Y. H. Liu, K. T. Wong, J. Wen, D. J. Miller and S. B. Darling, Journal of the American Chemical Society, 2012, 134, 13616-13623.

40. J. Zhou, X. Wan, Y. Liu, Y. Zuo, Z. Li, G. He, G. Long, W. Ni, C. Li, X. Su and Y. Chen, Journal of the American Chemical Society, 2012, 134, 16345-16351. 
41. R. Fitzner, E. Mena-Osteritz, A. Mishra, G. Schulz, E. Reinold, M. Weil, C. Korner, H. Ziehlke, C. Elschner, K. Leo, M. Riede, M. Pfeiffer, C. Uhrich and P. Bauerle, Journal of the American Chemical Society, 2012, 134, 11064-11067.

42. D. Morisaki, H.-S. Kim, H. Inoue, H. Terauchi, S. Kuge, A. Naganuma, Y. Wataya, H. Tokuyama, M. Ihara and K. Takasu, Chemical Science, 2010, 1, 206209.

43. S.-Y. Liu, M.-M. Shi, J.-C. Huang, Z.-N. Jin, X.-L. Hu, J.-Y. Pan, H.-Y. Li, A. K. Y. Jen and H.-Z. Chen, Journal of Materials Chemistry A, 2013, 1, 2795-2805.

44. W. Aloui, T. Adhikari, J.-M. Nunzi, A. Bouazizi and K. Khirouni, Materials Science in Semiconductor Processing, 2015, 39, 575-581.

45. W. Aloui, T. Adhikari, J.-M. Nunzi and A. Bouazizi, Materials Research Bulletin, 2016, 78, 141-147.

46. P. J. Goutam, D. K. Singh and P. K. Iyer, The Journal of Physical Chemistry C, 2012, 116, 8196-8201.

47. S. Nikitenko, J. Mayorova, P. Troshin, R. Lyubovskaya and M. Kaplunov, Molecular Crystals and Liquid Crystals, 2007, 468, 239/[591]-244/[596].

48. G. Li, V. Shrotriya, J. Huang, Y. Yao, T. Moriarty, K. Emery and Y. Yang, Nature materials, 2005, 4, 864-868.

49. W. Zhao, D. Qian, S. Zhang, S. Li, O. Inganäs, F. Gao and J. Hou, Advanced materials, 2016, 28, 4734-4739.

50. A. Moliton and J. M. Nunzi, Polymer International, 2006, 55, 583-600.

51. D. H. Kim, D. Y. Lee, H. S. Lee, W. H. Lee, Y. H. Kim, J. I. Han and K. Cho, Advanced materials, 2007, 19, 678-682.

52. S. R. Forrest and M. E. Thompson, Chemical Reviews, 2007, 107, 923-925.

53. J. Rivnay, L. H. Jimison, J. E. Northrup, M. F. Toney, R. Noriega, S. Lu, T. J. Marks, A. Facchetti and A. Salleo, Nature materials, 2009, 8, 952-958.

54. R. Street, M. Schoendorf, A. Roy and J. Lee, Physical Review B, 2010, 81, 205307.

55. B. Walker, A. B. Tamayo, X. D. Dang, P. Zalar, J. H. Seo, A. Garcia, M. Tantiwiwat and T. Q. Nguyen, Advanced Functional Materials, 2009, 19, 30633069. 
